\title{
Ethical Responses to Modern Clinical Trials on Human Subjects: A Comparative Perspective
}

\author{
Tariq Abdul Razak ${ }^{1}$ \& Abdurezak Abdulahi Hashi ${ }^{2}$ \\ ${ }^{1}$ Kulliyyah of Medicine, International Islamic University Malaysia Kuantan \\ ${ }^{2}$ Kulliyyah of Science, International Islamic University Malaysia Kuantan
}

\begin{abstract}
With the modern advances and technological breakthroughs in biomedicine, scientific experiments involving human subjects had increased. Since the American gynecologist Marion Sims (d.1883), who conducted a scientific research on some selected African women suffering from prolapsed uterus disease, or American physician Walter Reed's (d.1902) team who gave germs of yellow fever to 22 human subjects to test if fever is transmitted by particularly mosquito species, as well as the Tuskegee Syphilis Study that was conducted from 1932 until 1972, or the scientific experiments conducted by Nazis of Germany on large numbers of prisoners, clinical trials on human subjects have become part of the scientific activities. These and many other scientific experiments conducted on human subjects had shown the extent of potential threats of unregulated scientific experiments on human life. Serious moral and legal concerns are then raised towards the morality of these activities. These concerns covered four major areas; safety, sanctity of the human body, consent and validity of experiment. This paper uses textual and analytical methods and aims to review Muslim jurists' opinions on the permissibility of conducting clinical researches that uses human subjects. The opinions of the Muslim jurists are then compared to that of bioethical codes and declarations such as the Nuremberg Code, coined in (1947) and the Helsinki Declaration that was formulated by World Medical Organization in 1964. Figh and legal literature on this subject is exposed, and the moral contents of such writings are analyzed. The study is expected to come up with a comparative account of conventional and Islamic responses to modern clinical trials on human subjects.
\end{abstract}

KEYWORDS: Scientific experiments, human subjects, jurists’ opinions, declarations, analysis

\section{INTRODUCTION}

One of the basic biomedical researches that are set to improve our medical knowledge is clinical research. It is part of basic medical research, particularly experimental medicine that is characterized by the involvement of patients. For it involves scientific experimentation on human subjects, therefore this type of research raises moral and legal concerns. Among many questions in this regard is how far human body be used as experimental product in which given drugs are tested. If human body is used as a subject of scientific experimentation, does that contradict with the traditional beliefs about the sanctity of man's body?

With these concerns in mind, those scientists who engage with scientific researches that involve in experimentation with human subjects have to take into consideration two important issues, namely safety of the human subjects and the ethics in performing the experiments. Studies in animals provide useful information for answering questions

Corresponding author:

Abdurezak Abdulahi Hashi

Kulliyyah of Science

International Islamic University Malaysia, Jalan Sultan Ahmad Shah, 25200 Kuantan, Pahang, Malaysia

Email: hashi@iium.edu.my relevant to man. As human is the most sophisticated being, experiments on other less sophisticated beings (animals) tends to be over generalized when the results are applied to humans. Ethical aspects in animals becomes increasingly important as the animals that are used being more complex in nature, and generally the more complex the animal is, the more closely the results tend to be applicable to human. For studies of laboratory mice for instance, the results would be less likely to be similar to humans as compared to the results obtained from the primates. There are moves to use cell cultures to avoid the ethical issues faced. However, these cells are also living organisms taken from human bodies but assumingly without the 'soul' as that of an intact animals or humans. The disadvantage of such a study is that it may not represent the result that might be obtained using whole animals. Even if $\mathrm{t}$ whole animals are used, because of the differing complexity of the animal species, certain animals are more reflective of the human physiology than others. As such, several animal species are usually experimented on in determining or predicting the response that may occur in human. There has to be a balance of the type of animal used in experiment and the expected results being applicable to humans. Even then, one can never be absolutely sure that results obtained from animal studies is really applicable to man unless the experiment is conducted in man himself. As such, collection of data from planned 
IMJM Volume 17 Special Issue No 2

experimentation on human beings is necessary for the improvement of human health.

With modern advances and technological breakthroughs in biomedicine, scientific experiments involving human subjects have increased. For instance, in the middle of $19^{\text {th }}$ century, American gynecologist Marion Sims (d.1883) conducted scientific research on selected African women suffering from prolapsed uterus disease. Each of these women had undergone a number of surgeries without giving them anesthetic and as a result, many of them died. In 1900, the US Army physician, Walter Reed (d.1902) gave yellow fever virus to 22 human subjects. Reed's team postulated and confirmed that yellow fever is transmitted by a particular mosquito species. Then, from 1932 until 1972, the Tuskegee Syphilis Study (also known as Public Health Service Syphilis Study), was conducted in America which targeted Black Americans. In order to study the effect of frigid temperature on person suffering from mental disorders, a refrigeration experiment was conducted on 16 mentally disabled patients who were placed in refrigerated cabinets at 30 degree Fahrenheit for 120 hours, at the University of Cincinnati Hospital in 1943. Modern experiments involving human subjects reached to unprecedented climax when in early 1940s, the Nazis of Germany conducted a variety of scientific experiments on large numbers of prisoners subjecting them to head injuries, freezing temperatures, nerve gases, muscle and transplantations experiments. These and many other scientific experiments were conducted on human subjects and have shown the extent of the potential threats of unregulated scientific experimentation on human life. ${ }^{1}$

There are a number of relevant academic literatures on this topic that are worth mentioning, include among others the Nuremberg Code, formulated in 1947 , which consists of a set of ethics for medical research that involve human subjects. Similarly, in its meeting in Helsinki, in 1964, the World Medical Organization formulated the Helsinki Declaration; an ethical code that consists of ethical regulations for scientific experimentation involving human subjects. Another related ethical code that addresses ethics of clinical research is the Belmont Report, which was created by the United States' National Commission for the Protection of Human Subjects of Biomedical and Behavioural Research, in 1979. Useful moral discussions on clinical research ethics are also found in the books like The New Dictionary of Medical Ethics, edited by Kenneth M Boyd and others; Bioethics: Issues and Perspectives, written by Susan Scholle Connor and others, as well as Bioethics: An Introduction to the History, Methods, and Practice, by Nancy S. Jecker and others. From the Islamic perspective, Abdul Fadl Mohsin Ebrahim's two books on biomedical ethics, namely; Abortion, Birth and Surrogate Parenting: An Islamic Perspective, and Biomedical Issues: Islamic Perspective, in which the author incorporated an important discussion on ethics of clinical trials from
Islamic perspective are worth mentioning. Furthermore, the series of researches on various contemporary issues, including ethical issues of clinical trials from the perspective of the Islamic law and jurisprudence, ${ }^{\text {\& }}$ written by Arif Ali Arif, a professor of Islamic Jurisprudence at IIUM is also worth mentioning. Another important series which includes variety of important academic biomedical works related ethics of clinical trials is the journal of the Islamic Fiqh Academy (Majalah Majma'a alFigh al-Is(ämiyi), of the Organization of the Islamic Countries, in Jeddah. These and other valuable academic works on medical ethics have enriched the discussions and subjects of this paper.

\section{The scope of clinical research ethics}

Experiments ranges from those undertaken as part of patient care to those undertaken either in patients or healthy subjects for the purpose of contributing to knowledge and it includes investigation on human behavior. Therefore, investigators are reminded that they have ethical and legal responsibilities toward their subjects. Clinical experiments consist of two main aspects; (1) scientific aspect and (2) ethical aspect; sometimes there may be a clash of interest in these two aspects. It is recommended that institutions have separate committees to look into these two aspects. At the International Islamic University Malaysia, two separate independent committees are established for this purpose. The main aim of these committees is to establish that the benefit of the human experimentation is reasonable in terms of the patient/ volunteer, advances in patient care, clinical research support facilities, hospital cost and reputation of the investigator(s). The scientific committee looks at the scientific aspects of the experiment, and whether the experimental procedures and design could possibly answer the question(s) that are being posed. The composition of the committee members consists of experienced researchers and senior medical scientists. If the experiment is not scientific, it would not be approved and may not even be brought to the ethical committee to be discussed. If it is not scientific, it is unethical to proceed with the experiment. Because of the composition of the committee is such, it is inherently bias towards the interest of the researchers. The ethical committee on the other hand, looks at the ethical aspects of the experiment. This committee represents the community from which the subjects are being recruited. It is to represent the interest of the subjects under study and the course of the study to be monitored.

It has been suggested that the members be composed of men and women reflecting the different age groups and members of the society and include at least; a person not associated with the institution. a minister of religion, a lawyer, a medical graduate with research experience, a laywoman and a layman. One person could reflect the interest of more than one of the above. Ethics itself is not an exact science, that there are many 
issues to which the question of right or wrong cannot be given a simple answer, and that there are some matters that cannot be settled by consensus. When an activity is acceptable from the ethical standpoint, this will frequently mean not that it is clearly ethically right, rather that it is ethically defensible but may still be legitimately controversial.

In carrying out its function, the Institutional Ethics Committee should be; first guided by the principles outlined in the declaration of Helsinki on human experimentation. Second, take into account of local, cultural and social attitudes in making decisions. Third, ensure that the procedures related to obtaining informed consent are observed. Fourth, ensure that while accepting that doctors have a duty to advance knowledge by research, the rights of individual patients, or subjects of research take precedence over the expected benefits to human knowledge or to the community.

There are two major interests to serve in performing research, namely; the health of people generally and the health of the individual patient or volunteer. Concern for the interests of individual patient or volunteer must always prevail over the interests of science and society. The declaration of Helsinki states regarding informed consent as such, "If at all possible, consistent with patient's psychology, the doctor should obtain the patient's freely given consent after the patient has been given a full explanation. Consent should as a rule, be obtained in writing. However, the responsibility for clinical research always remains with the research worker, it never falls on the subject even after consent is obtained. Like any other medical records, every precaution must be taken to protect the privacy of the subjects and the confidentiality of their personal information and to avoid the impact of the study on their physical, mental, spiritual and social integrity.

\section{Some Issues concerning informed consent}

First, one of the main concerns in this regard is the research that involves children, whereby it is generally discouraged from doing a research on underage subjects. In principle, if the research can be done on adults, then it should not be done on children; however it is permissible if it is part of a therapeutic process or if the disease condition is that of children and not normally occurring in adults. Informed consent is by the legal guardian.

Second, another main concern is the research involving pregnant and nursing women, whereby pregnant females are not recruited because of the presence of the fetus which is regarded as an independent person from the mother. Experiments on the mother may affect the health of the fetus.

Third, another area that is of major concern is the research that involves the mentally ill individuals or minors. This is so because, these individuals may not have the insight into their condition and they are legally incompetent to give consent.

Fourth, ethical concerns are also made towards research involving prisoners, particularly those who are serving life time jail terms. It is tempting to do research on prisoners as they live in a closed environment that could be controlled from outside factors and the results can be more reliable. However, the expectation of early release from prison by participation may be considered as being biased and may not be acceptable.

\section{Process for obtaining informed consent}

1. The subjects / patients, or if mentally incapable, the legal representative, must be provided with a fair explanation of the project to be undertaken or the drug to be administered, with reference to all of the known major risks involved and the discomfort it may entail. The benefit : risk ratio should be assessed and made known to the patients

2. The patient should be asked if he or she wishes a family member or a friend to be present when the procedure of a research project is explained to him /her. It should be borne in mind that, under normal circumstances, if patient's wishes conflict with those of his / her family, the patient's wishes must be respected.

3. If possible, the consent to be given in writing. Consent must be given voluntarily and therefore situations in which there may be imposed limitations, as with medical students, prisoners, certain patients group, require special consideration.

4. The investigator, wherever possible should give the explanation him/herself. A responsible third party not concerned with the project, and not related to the patient, should be present when consent is being obtained for human experiments. The name of the third party should be noted on the consent form as witness and the investigator should sign as well.

Should there be any indication of unwillingness on part of the patient to participate, or the patient does not fully comprehend what is explained to him due to language difficulty or other causes, then the patient should not be included in the study.

\section{Islamic responses to clinical researches}

Islamic responses to clinical researches that involve human subjects begin with the Islamic understanding of knowledge expansion including that of medical science. As reflected in various Qur'anic verses, and in the tradition of the Prophet (s. a. w.), Islam promotes the culture of learning and increase of knowledge, whereby acquisition of knowledge is made mandatory upon all Muslim. This 
IMJM Volume 17 Special Issue No 2

includes the study of religious teachings such as basic articles of faith, methods and styles of performing religious duties, norms of social order, social and psychology of given members of the society, as well as readings on the natural environment by means of scientific research through close observation and experimentation. Medicine is of course among the basic subjects of scientific knowledge. For it involves prevention and saving life, medicine forms an imperative subject within the Islamic tradition of learning.

Based on the principle "God never inflicts a disease without providing a cure for it" as well as with the teaching that "He who put diseases on earth, has also put its remedy there" (reported by Tirmidzi), Islam requires its adherence to increase healthcare and healing practices. As stated in these principles, Islam allows variety of medical treatments that are set to reverse disease pathology, mitigate its effects or stop further progress of its effect. It also allows using natural plants and products, as well as manufactured chemicals and surgical operations which are designed to correct reformatory baths of the body or to remove diseased tissues or perhaps to replace damaged cells and organs of the body. In accordance with the above stated principles of seeking cure for all diseases, Islam also allows scientific activities and practices that are designed to increase our understanding of the causes and the nature of given ailments, as well as the functions and the efficiency of drugs and related healing practices. Clinical research is no exception from this principle, whereby Muslim scientists are required to expand their clinical knowledge and skill so that given illnesses are duly treated.

However, with regards to morality of clinical trials, Islam set ethical guidelines that are designed to govern medical researches involving human subjects. The Islamic ethical guidelines are however closely related to that of conventional ethical guidelines for clinical researches as reflected in the Helsinki Declaration, and in other related medical guidelines of clinical researches. The Islamic Organization of Medical Sciences (IOMS), based in Kuwait, and other Muslim scholars of Islamic jurisprudence elsewhere in the Muslim world like Egypt have discussed the Islamic ethical guidelines on clinical researches in relation to the Helsinki Declaration, the results of these deliberations were published as the International Ethical Guidelines for Biomedical Research involving Human Subjects: "An Islamic Perspective. It generally includes the agreed ethical principles such as respect of person, beneficence, non maleficence, and justice, Muslim jurists have accepted the dictums of the Helsinki Declaration. Similar to the Declaration of Helsinki, Islamic ethical guidelines of clinical researches stress the need for distinguishing between researches that are basically therapeutic or diagnostic in nature, and medical researches, the essential objectives of which are purely scientific without direct diagnostic or therapeutic value to the person subjected to research. Muslim jurists noted that clinical research should be conducted in a dignified manner that honours human life, health, dignity and rights.

\section{General ethical principles}

The general ethical principles for clinical research are part of the Islamic ethical teachings. For instance, in chapter 17, verse 71, the Qur'an states that Almighty, Allah (s.w.t.) has "honoured the children of Adam". The teachings of this and related verses in the Qur'an, connote that man and woman are privileged (karamah) with the various faculties which should be respected. People's right to make decisions of their choice is part and parcel of their honour and dignity. This implies that, as "no one is entitled to dispose of the right of human being without his permission," participation in clinical trials should be achieved only by means of voluntary consent. Second, Muslim jurists often mention that the shari'ah aims to bring benefit (jalb al-manfa'ah) and prevent harm (daf'u aldarar). All forms of harm are prevented, while real and perceived benefits are sought, a principle that sounds very much inline with the medical principle of "beneficent". This principle entails that one ought not to inflict harm, rather, one ought to prevent harm, and thus promote good. Third, another moral principle is non maleficence, which signifies the obligation of inflicting no harm to anyone intentionally. The Islamic shari'ah teaches that harm should not be inflicted nor reciprocated (la darara wala dirara). This is to say in the process of conducting clinical research respective medical doctors and researchers ought not to initiate any harm knowingly on any patient. From the Islamic ethical perspective "every action that leads to harm or that prevents a benefit is forbidden." Fourth, as reflected in chapter 5 , verse 8 , as well as chapter 6 , verse 135, and elsewhere in the Qur'an, among the basic teachings of Islam is to "be just", "stand out firmly for justice" and witness "fair dealing" in all matters of life, including medical researches. Justice in medical practices entails to treat people fairly with due respect of the patients, regardless of their race or social status. Favouritism, prejudicial behaviour and other forms of discrimination run counter to medical ethics.

\section{Ethical guidelines}

As mentioned earlier, in principle, Muslim jurists permitted the conduct of clinical researches involving human subjects, as long as these researches are conducted with due research ethics and medical care principles.

First, the objectives of given clinical researches should be morally justified, and comply with the Islamic Divine teachings. The intended aims of given clinical researches must be absolute and certain. Once its design is done according to the scientific standards, with qualified research team, its means should not violate or contradict with the established norms of the shari'ah. Similarly, based on the jurisprudential principle that states "whatever it 
takes to fulfil given obligations are also considered as an obligation", clinical researches become an obligatory task to save life, but as the last resort or option, hereby, other means of medical treatments and practices are proven less effective to achieve the intended aims.

Second, based on the Qur'anic verses like verse 43, chapter 16, that states to require advise of those endued with knowledge in given specialisations, Muslim jurists agreed to form a supervisory committee that monitors the process of given clinical trials. This supervisory committee should conduct regular checks and evaluation of given research activities, funds and related subjects with due responsibility, honesty and objectivity. This entails collective effort (ta'wun and shura) of all relevant bodies to secure the intended benefits and prevent harm.

Third, based on the jurists' principles like: "no one is entitled to dispose of the rights of a human being without his permission", and "no right of a human being can be canceled without his consent," Muslim jurists required that clinical researches that involve human subject must obtain informed consent from the prospective participants. This consent must be obtained prior to research commencement. Researchers are required to expose essential informations related to the benefits, aims, methods, sources of funding and potential harms to the participants, thus consents obtained by means of concealment or through coercive measures are not valid. This is so because, in the Islamic jurisprudence "mutual agreement cannot be reached under conditions of ignorance" and "consent to an unknown thing and acquittal from an unknown thing are not valid." Participants of the clinical research should also be informed about their right to abstain from participation or to withdraw from the study without any punishment. In addition, prospective research subjects should be mentally sane and sound; minors and legally incompetent people are not permitted to give consent.

Fourth, from the Islamic ethical perspective, it is not obligatory to compensate the losses or the financial cost incurred by the subjects involved in the research. Yet, based on the Islamic teachings of justice and fairness, as well as the Prophetic teachings that dictates, "give incentives to those

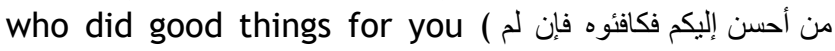
Muslim jurist agreed to the morality of paying undue incentives and payments in the form of transportation and other financial cost incurred by the respective subjects of the research.

Fifth, the need to strike a balance between potential benefits and risks in research involving human subjects, with the prospective benefits being more likely and the need to minimize risks, is included in the basic principle of Islamic ethical guidelines for researches involving human subjects. If let us say "a less substantial instance of harm and an outweighing benefit are in conflict, the harm is forgiven for the sake of the benefit." Similarly, also a specific harm is tolerated in order to prevent a more general one, i.e., yutahammal ad-darar alkhaas li-daf'al-darar al "aam".

Sixth, justice and equality are required in the instances of conduct of research in communities and populations with limited resource, choice of controls in clinical trials, or research involving with vulnerable persons, or children.

Seventh, women of reproductive age could be the subject of clinical research for the benefit of reproductive woman's health. However, moral issues related to the involvement of pregnant woman in clinical researches are not straight forward.

Eighth, confidentiality and the right of privacy, as well as the right of treatment from incurred injures or damages as result of given clinical experiment are granted for the research subjects from the Islamic perspective.

\section{REFERENCES}

1. Hashi, Abdurezak A. Bioethics: A Comparative Study of its Concept, Issues and Approaches. Kuala Lumpur: IIUM Press. 2015.

2. Encyclopaedia of Alabama: Available at: http:// www.encyclopediaofalabama.org/face/Article. Accessed on 16/07/2012.

3. Walter Reed's Yellow Fever Collections: Available at: http://

yellowfever.lib.virginia.edu/reed/reed.html. Accessed on $08 / 10 / 2016$.

4. A Brief History of Human Experiments. Available at: http://www. mnwelldir. org/ docs/history/experiments.htm. Accessed on 08/10/2016.

5. Trials of War Criminals Before the Nuremberg Military Tribunals under Control Council Law No. 10 October 1946 - April 1949: Available at: http:// www.loc.gov / rr/frd/ Military_ Law/NTs_war-criminals.html. Accessed on $11 / 07 / 2012$.

6. Helsinki Declaration. Available at http:// www.ncbi.nlm.nih.gov/pmc/articles/PMC181610 2/pdf/brmedj02559-0071.pdf. Accessed on $11 / 07 / 2012$.

7. Belmont Report: Ethical Principles and Guidelines for the Protection of Human Subjects of Research, Report Of the National Commission for the Protection of Human Subjects of Biomedical and Behavioural Research; Department of Health, Education, and Welfare. Available at

(http://www.hhs.gov/ohrp/archive/documents/ 19790418.pdf). Accessed: 11/07/2012).

8. Kenneth M Boyd, Roger Higgs and Anthony J Pinching, The New Dictionary of Medical Ethics. London: BMJ Publishing Group, 1997.

9. Susan Scholle Connor, Hernan L. FuenzalidaPuelma, Bioethics: Issues and Perspectives. 
Washington: Pan American Health Organization, 1990.

10. Nancy S Jecker, Albert R Jonsen, Robert A Pearlman, Bioethics: An Introduction to the History, Methods, and Practice. Boston: Jones and Bartlett Publishers, 2007.

11. Abdul Fadl Mohsin Ebrahim, Abortion, Birth and Surrogate Parenting: An Islamic Perspective. USA: Americal Trust, 1989.

12. Abdul Fadl Mohsin Ebrahim, Biomedical Issues: Islamic Perspective. Kuala Lumpur: A. S. Noordeen, 1993.

13. Arif Ali Arif, MasĀ'il Shar'iyyah fī Qadāya alMar'ah. Kuala Lumpur: IIUM Press, 2011.

14. Arif Ali Arif, QadĀya Fiqhiyyah fĩ Naql al-'Ada al-Bashariyyah. Kuala Lumpur: IIUM Press, 2011.

15. Majalah Majma'a al-Fiqh al-Islämiyi. OIC: alDawrah al-Rābi'ah li-Mu'tamar Majalah Majma'a al-Fiqh al-Islāmiyi, vol. 1, $4^{\text {th }}$ issue 1988.

16. International ethical guidelines for biomedical research involving human subjects "an Islamic perspective." In El-Gendy AR, Al-Awadi ARA, editors. The international Islamic code for medical and health ethics. Kuwait: Islamic Organization for Medical Sciences; 2005: Vol 2, 121-276. 